\title{
The Relationship between Components of Work Engagement and Organizational Commitment of Female Employees of University
}

\author{
Fatemeh Forootan Eghlidi \\ M.A in Public Management, Isfahan (Khorasgan) Branch \\ Islamic Azad University, Isfahan, Iran \\ Fariba Karimi (Corresponding author) \\ Department of Educational Sciences, Isfahan (Khorasgan) Branch \\ Islamic Azad University, Isfahan, Iran \\ Email: faribakarimi2005@yahoo.com
}

Received: July 02, 2016 Accepted: August 10, 2016 Published: October 01, 2016

doi:10.5296/ijhrs.v6i3.9689 URL: http://dx.doi.org/10.5296/ijhrs.v6i3.9689

\begin{abstract}
Aim: The present research was conducted with the aim of determining the relationship between the components of work engagement and organizational commitment of female employees working at University of Isfahan.

Methods: The type of the research was an applied research by purpose and a descriptive correlational-type research by nature. The study population consisted of female employees at University of Isfahan, 428 individuals, of whom 202 individuals were chosen as sample according to stratified random sampling fit for the size. The measuring instrument was a questionnaire about organizational commitment by Mowday el al and a questionnaire on work engagement by Shaufeli et al. In the analysis of the findings of the research, Pearson correlation coefficient, stepwise regression, and multiple-way analysis of variance were used to examine the research hypotheses.

Result: The results of the analyses indicated that correlation coefficient between work engagement and its components vigor (the desire for job), dedication, and absorption and organizational commitment is significant. Among the components of work engagement, dedication to work was the best predictor for organizational commitment. No significant
\end{abstract}


difference was observed between opinions of respondents according to demographic factors concerning work engagement and organizational commitment.

Conclusions: Manager implement professional standards and rules in organizations in order to maintain and promote the variables, provide employees with freedom of action and power in accordance with their duties and provide an intimate climate by involving them in decision makings.

Keywords: Work engagement, Organizational commitment, Female employees

\section{Introduction}

In the present world, organizations have reached an ideal position in the structure of a society. For this reason, having healthy and efficient organizations is considered important and necessary. There are many factors contributing to the success and productivity of an organization, including paying attention to the discussion of human resource and employees. [1]

Therefore, today with experience and research on different fields of management, management scholars came to the conclusion that human resource is an invaluable part and vital capital of every organization, so paying attention to attitudes and factors associated with human resource can increase performance and efficiency in an attempt to achieve organizational objectives. However, it should be admitted that knowledge on attitudes of employees has little importance to managers, as they actually are more interested in knowing types of attitudes associated with work and organization. One of the important attitudes in the field of work and organizational activity is organizational commitment ${ }^{[2] . ~ E x p e r t s ~ a n d ~}$ specialists in management science have come up with a variety of definitions of organizational commitment:

Gautman $^{[3]}$ states that organizational commitment is an attitude or orientation toward organization that relates individual identity to an organization ${ }^{[4]}$. He contends that commitment is the tendency for doing continuous activities in order to save capital, in that one leaves it, the savings will disappear ${ }^{[5] . ~ C o m m i t m e n t ~ h a s ~ b e e n ~ d e f i n e d ~ a s ~ i n d i v i d u a l s ' ~}$ tendency for taking energy and loyalty to a social system. For Lee and Handerson [6], organizational commitment is a relatively sustainable attitude reflecting individual's desire for being loyal to organization in the workplace. In this account, the sub-components of organizational commitment has been defined as firm belief in goals and values of organization, desire for further effort in organization and passionate desire for remaining in organization. Mowday et $\mathrm{al}^{[7]}$ found organizational commitment to be comprised of three components namely belief in goals and values of organization, desire for putting effort into achieving organization's goals, and relatively strong desire for remaining in organization. Mowday et al ${ }^{[8]}$ believe that a committed employee has strong obligation to organization's goals and values, defines his identity under the umbrella of organizational identity, has greater contribution to organizational affairs, and enjoy his membership in organization ${ }^{[9]}$. O'reilly and Chatman ${ }^{[10]}$, in their research, identified three levels for organizational 
commitment: acceptance, identification, and internalization. As for acceptance in the levels of organizational commitment, person acknowledges the influence of others and seeks benefit in return. At the beginning of his arrival to organization and his membership in the organization, commitment is given and adaptation is made, and individual receives bonuses by agreeing to orders. In identification level, person goes along with influences so as to reach a favorable and good relationship with organization. Commitment is here referred to as continuation and desire for communication and appeals to individual. In internalization level, which is the last phase, individual found organizational commitment to be internal incentives compatible with his values; in other words, at this level, individual's values and those of organization match up and are seen as a job center in order to boost motivation and sense of responsibility of organization's members.

As a result, organizational commitment is a key factor in understanding organizational behavior and a good predictor of desire for remaining in job ${ }^{[11]}$. Research has shown that organizational commitment affects outputs of an organization namely intention to leave, sales and profitability of organization and absenteeism of employees ${ }^{[12] .}$

Sulu et al ${ }^{[13]}$ state that employees committed to organization prefers remaining in organization, even if they are offered more compelling alternatives. Committed individuals have strong desire for remaining in organization, because they have agreed to organizational values and goals personally and become actively involved in organizational activities ${ }^{[14]}$. As with a source of energy and power, committed individuals move toward their aspirations and goals. Committed individuals do not simply rely on existing rules and structures, nor do they confine themselves to their framework. They attempt to change rules or structures and remove existing obstacles, if they run into them ahead of their path.

Given the studies conducted by Bakker et al ${ }^{[15]}$, Amin Bidokhti and Salahpour ${ }^{[16]}$ hold that there is a growing consensus about desire which can refer to high level of energy and work engagement ${ }^{[17]}$. Therefore, in addition to organizational commitment, work engagement is also another factor influencing success of organizations. Work engagement is a concept positively associated with positive tokens such as job performance and job satisfaction and negatively associated with intention to leave, and has three aspects namely vigor (desire for work), dedication, and absorption ${ }^{[18] .}$

Shaufeli and Bakker ${ }^{[19]}$ also define work engagement as a positive mental state toward job, which is identified by characteristics such as desire for work, dedication, and absorption in work $^{[20] .}$ It provides a positive experience and affects work life and bring organization great advantages accordingly.

In the previous years, numerous studies have been conducted into work engagement and organizational commitment in different organizations and department throughout the country, through which the amount of the two variables has been reported differently from one organization to another. Given that the amount of the two variables is declining in organizations and has been affecting the performance of organizations, managers set out to know why organization fail to make progress despite their skilled and efficient labor, which is the major indicator of the superiority of an organization over other organizations, while 
absenteeism, delay and staff turnover have been increasing, which has made organizations fall behind in their goals ${ }^{[21] .}$

A group of researchers also believe that desire comes from two concepts, and has been scientifically recognized and become the subject of many experimental studies; organizational commitment and organizational citizenship behavior ${ }^{[22]}$. For example, Parsamoein and Nazem ${ }^{[23]}$, in a research entitled relationship between entrepreneurship and organizational commitment and job burnout, introduced organizational commitment as a consequence of work engagement; therefore, organizations are in need of energetic and passionate employees in order to remove existing problems.

Thus, considering the importance of the variables work engagement and organizational commitment, as well as paying attention to the importance of University of Isfahan for providing the suitable foundations for using women's abilities in society, an attempt was made in this study to explore the relationship of the components of work engagement to organizational commitment of female employees of University of Isfahan, so that by determining the relationship between the variables and confirmation of the relationship managers can boost female employees' organizational commitment by providing work engagement for them, preventing them from leaving their work, so they can benefit from women's empowerment more favorably.

Kave and Ganji ${ }^{[21]}$ conducted a research entitled "relationship of the level of organizational commitment to work engagement among employees of Agriculture Jihad Organization and Shahre Kurd Education Organization". The results indicated that a direct relationship exists between organizational commitment and work engagement, a correlation between the subscales of work engagement namely dedication, absorption, and vigor and organizational commitment and its subscales. Simons et al ${ }^{[24]}$, in a research entitled "psychological capital, work engagement and organizational commitment amongst call center employees in South Africa, found a positive and significant relationship between psychological capital, work engagement and organizational commitment. The results indicated that work engagement was the only indicators that could predict organizational commitment. Noori et al ${ }^{[25]}$ conducted a research entitled "relationship of the components of work engagement to dimensions of organizational commitment. The results indicated that a significant correlation exists between components of work engagement and dimensions of organizational commitment. Furthermore, among the components of work engagement, dedication was the best predictor of organizational commitment. Burke and Elkote ${ }^{[26]}$, in a research conducted on managers and experts of different organizations in Egypt, demonstrated that work engagement is significantly and negatively related to intention to leave. In a meta-analysis performed concerning work engagement, a strong significant relationship was reported between work engagement and intention to leave organization with a correlation coefficient ranging from 0.25 for desire for work to 0.45 for absorption in work. In a meta-analysis conducted on 2308 teachers, Hakanen et al ${ }^{[18]}$ explored teachers' burnout and work engagement, concluding that experimental evidence upholds a positive and significant relationship between work engagement an and organizational commitment. Richardson et al ${ }^{[27]}$, in a research conducted on 150 Norwegian police officers, concluded that work engagement is a mediator of the 
effects of personality traits, job demands and job resources on organizational commitment.

The aim of the research is to determine the relationship of the components of work engagement to organizational commitment of female employees at University of Isfahan. Thus, given the aim of the research, the following hypotheses are concerned:

1- A relationship exists between work engagement and organizational commitment of female employees at University of Isfahan

2- Components of work engagement have predictability for organizational commitment of female employees working at University of Isfahan.

3- There is a difference between opinions of respondents about work engagement, organizational commitment, considering demographic variables (age, education degree, type of employment, job tenure, and organizational position).

\section{Methods}

\subsection{Participants}

The study population consisted of female employees at University of Isfahan, i.e. a number of 428 employees of whom 202 individuals were chosen using stratified random sampling compatible with the size. Afterward, they were chosen for each part randomly. The demographic characteristics of the research sample indicated that of 428 individuals 53.3 percent of the women participated in the research were in the group age 30 to 40 years, and 44.7 percent of them had bachelor degree. 56.6 percent of the study sample were employed on contractual basis, and 50.8 percent had a job tenure from 11 to 20 years. On the whole, of 202 questionnaires distributed among female employees, a number of 199 questionnaires were collected. In order to collect information, a standard questionnaire on work engagement by Shaufeli et al ${ }^{[28]}$, which contains 17 items with a 7-point scale from always to never, was used, and the three aspects vigor (desire for work), dedication, and absorption in work were measured. The numerical value 0 to 6 was set for options. The reliability of the questionnaire was calculated to be 0.83 using Cronbach's alpha coefficient. For measuring organizational commitment, organizational commitment questionnaire by Mowdey et al ${ }^{[29]}$ with 19 items and seven-point scales was used. The questionnaire constitutes the dimensions firm belief in goals and values of organization, desire for further effort in organization and desire for remaining in organization. The reliability of the questionnaire was estimated to be 0.90 using Cronbach's alpha coefficient. In this research, the method was descriptive and correlational. It was an applied research by nature. For the analysis of the research findings, Pearson correlation coefficient, stepwise regression and multiple-way analysis of variance test along with SPSS 19 software program were used.

\section{Findings}

\subsection{First Hypothesis}

The results of table 1 indicate that the coefficient of the correlation between the components of work engagement (absorption in work, desire for work, dedication) and organizational 


\section{Al Macrothink}

International Journal of Human Resource Studies

ISSN 2162-3058 2016, Vol. 6, No. 3

commitment is significant; that is, a significant relationship exists between work engagement and organizational commitment $(\mathrm{r}=0.257)$.

\subsection{Second hypothesis}

The results of table 2 suggest that among the variables of interest in the regression the best predictor of organizational commitment is dedication to work in the first stage. According to the results of stepwise regression analysis, the relationship between the components dedication and organizational commitment was significant. Accordingly, in the first step, the coefficient of dedication can explain 27.9 percent of the variance of organizational commitment.

\subsection{Third hypothesis}

The results of table 3 show that there is no significant difference between opinions of the respondents about work engagement and organizational commitment, considering the demographic variables (age, education degree, type of employment, job tenure, and organizational position).

Table 1. Correlation between the components of work engagement and organizational commitment

\begin{tabular}{llll} 
Dependent variables & Organizational commitment & \\
\hline Sredictor variable & & $\mathrm{R}^{2}$ & $\mathrm{P}$ \\
\hline Work engagement & $* * 0.257$ & 0.066 & \\
\hline Vigor & $* 0.187$ & 0.034 & 0.001 \\
\hline Dedication & $* * 0.203$ & 0.041 & 0.012 \\
\hline Absorption & $* * 0.291$ & 0.084 & 0.006 \\
\hline & $* * \mathrm{p}<0.01$ & & 0.000 \\
\hline
\end{tabular}


Table 2: Power of the components of work engagement for predicting organizational commitment

\begin{tabular}{|c|c|c|c|c|c|c|c|c|c|c|c|}
\hline \multicolumn{2}{|c|}{ Indicators } & \multirow{2}{*}{$\begin{array}{l}\text { Predictor } \\
\text { variable }\end{array}$} & \multicolumn{2}{|c|}{$\begin{array}{l}\text { Un-standardiz } \\
\text { ed } \\
\text { Coefficients }\end{array}$} & \multirow[t]{2}{*}{ Beta } & \multirow[t]{2}{*}{$\mathbf{t}$} & \multirow[t]{2}{*}{$\mathbf{P}$} & \multirow[t]{2}{*}{$\mathbf{R}$} & \multirow[t]{2}{*}{$\mathbf{R 2}$} & \multirow[t]{2}{*}{$\mathbf{F}$} & \multirow[t]{2}{*}{$\mathbf{P}$} \\
\hline $\begin{array}{l}\text { Depe } \\
\text { varis }\end{array}$ & $\begin{array}{l}\text { Ident } \\
\text { les }\end{array}$ & & B & $\begin{array}{l}\text { Std. } \\
\text { Error }\end{array}$ & & & & & & & \\
\hline 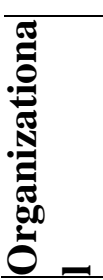 & 离 & $\begin{array}{l}\text { Absorptio } \\
\text { n }\end{array}$ & $\begin{array}{l}0.21 \\
8\end{array}$ & 0.058 & 0.279 & 3.741 & 0.000 & $\begin{array}{l}0.27 \\
9\end{array}$ & $\begin{array}{l}0.07 \\
8\end{array}$ & $\begin{array}{l}13.99 \\
2\end{array}$ & $\begin{array}{l}0.00 \\
0\end{array}$ \\
\hline
\end{tabular}

Table 3. Multiple-way analysis of variance of the scores of work engagement and organizational commitment

\begin{tabular}{|c|c|c|c|c|c|c|}
\hline source & variables & $\begin{array}{l}\text { Sum } \\
\text { squares }\end{array}$ & of $\mathrm{df}$ & Mean square & $\mathrm{F}$ & $\mathrm{p}$ \\
\hline \multirow[t]{3}{*}{ age } & \multirow{3}{*}{$\begin{array}{l}\text { organizational } \\
\text { commitment } \\
\text { work } \\
\text { engagement }\end{array}$} & 0.103 & 2 & 0.052 & 0.053 & 0.949 \\
\hline & & 0.096 & 2 & 0.048 & 0.046 & 0.955 \\
\hline & & & & & & \\
\hline \multirow{3}{*}{$\begin{array}{l}\text { Degree } \\
\text { education }\end{array}$} & \multirow{3}{*}{$\begin{array}{l}\text { organizational } \\
\text { commitment } \\
\text { work } \\
\text { engagement }\end{array}$} & 5.196 & 2 & 2.598 & 2.656 & 0.083 \\
\hline & & 0.804 & 2 & 0.402 & 0.383 & 0.685 \\
\hline & & & & & & \\
\hline \multirow{3}{*}{$\begin{array}{l}\text { Type of } \\
\text { employment }\end{array}$} & \multirow{3}{*}{$\begin{array}{l}\text { organizational } \\
\text { commitment } \\
\text { work } \\
\text { engagement }\end{array}$} & 5.099 & 2 & 2.549 & 2.607 & 0.087 \\
\hline & & 3.310 & 2 & 1.655 & 1.577 & 0.220 \\
\hline & & & & & & \\
\hline Job & organizational & 2.364 & 2 & 1.182 & 1.209 & 0.310 \\
\hline
\end{tabular}




\begin{tabular}{lllllll}
\hline experience & commitment & 0.564 & 2 & 0.282 & 0.269 & 0.766 \\
& $\begin{array}{l}\text { work } \\
\text { engagement }\end{array}$ & & & & & \\
& & & & & \\
\hline $\begin{array}{l}\text { Organizational } \\
\text { post }\end{array}$ & $\begin{array}{l}\text { organizational } \\
\text { commitment }\end{array}$ & 2.215 & 2 & 1.107 & 1.132 & 0.333 \\
& 0.255 & 2 & 0.127 & 0.121 & 0.886 \\
& $\begin{array}{l}\text { work } \\
\text { engagement }\end{array}$ & & & & & \\
\end{tabular}

\section{Discussion and Conclusion}

The results of the research indicated that the correlation coefficient between the components of work engagement (absorption, desire for work, dedication) and organizational commitment is significant; therefore, the first hypothesis is confirmed. The result of the first hypothesis is in agreement with the findings of Kave and Ganji ${ }^{[21]}$, concerning a positive and significant relationship between work engagement and organizational commitment, components of organizational commitment and work engagement, and components of work engagement and organizational commitment, and those of Noori et al ${ }^{[25]}$ and Hakanen et al ${ }^{[18]}$, and Richardson et al ${ }^{[27]}$ and Simons et al ${ }^{[24]}$ and Field and Buitendach ${ }^{[30]}$, concerning a positive and significant relationship between work engagement and organizational commitment, and the research by Burke and Elkote ${ }^{[26]}$ and the research by Halbesleben ${ }^{[31]}$, concerning a positive and significant relationship between work engagement and intention to leave work.

According to the results of the hypothesis, if jobs are designed as they can experience higher level of energy and pride in doing it and forget everything around it by focusing on the job deeply, they can eagerly move toward aspirations and goals of organization, and express desire for continuing their relationship with organization, as well as adhering to the organization. As a result, they would find organizational values to be internal incentive and compatible with their own values, so their organizational commitment will increase.

The results of the regression indicated that among the variables of the research in the regression the best predictor of organizational commitment is dedication to work. The results of the second hypothesis are in line with those of Noori et al ${ }^{[25]}$ and Simons et al ${ }^{[24]}$.

According to the results of the hypothesis, we can admit that if female workers know that organization needs them or they are important for the realization of organization mission, they will experience sense of loyalty and eager for doing work. Therefore, a positive experience is provided for employees and has desire for work with a positive mental state and their work engagement increases. As a result, they agree to goals and values of organization and see them in line with their goals; this would lead to great contribution to organizational affairs and they enjoy being part of organization. The result indicated that the explanation is true among the female workers of University of Isfahan; those female employees who dedicated themselves more to work than other colleagues and experienced sense of more 
eagerness and pride had more desirable performance and showed further organizational commitment.

Given the results, we can offer the following suggestions in order to invoke work engagement and organizational commitment:

1. Establish a strong employee-manager relationship in order to invoke work engagement in employees and spread positive consequences of such action to organization

2. Lay special emphasis on work engagement and encourage it among employees through building culture

3. Considering the positive relationship between work engagement and organizational commitment, manager implement professional standards and rules in organizations in order to maintain and promote the variables, provide employees with freedom of action and power in accordance with their duties and provide an intimate climate by involving them in decision makings so as to benefit from eager employees in organization and boost their organizational commitment accordingly.

\section{References}

Akhbari, M. Arizi, H.R. Alavi, S.K. (2010). Relationship of organizational commitment and its dimensions to professional commitment amongst the employees of Isfahan Refinery. Research and Scientific Journal Management and Human Resource in Petroleum Industry, 4(12): $129-157$

Habbibi, Kh. Kolaee, A. Rashidvand, J. Gharibvand, H.R. (2012). Study of the relationship of value-laden systems to organizational commitment of employees of Education Organization in Izeh City. Journal of Occupational and Organizational Consulting. 5(14): 45- 65

Gautam T, Van Dick R, Wagner U. (2004). Organizational identification and organizational commitment: Distinct aspects of two related concepts. Asian Journal of Social Psychology; (7):301-315.

Lee K, Alen NJ, Meyer JP, Rhee KY. (2001). Cross-cultural generalizability of the Three Component Model of organizational commitment: An application to South Korea. Applied Psychology: An International Review; 50: 596-614.

Meyer JP, Stanley JP, Herscovitch L, Topolnytsky L.(2002). Affective, continuance and normative commitment to the organization: a meta-analysis of antecedents, correlates and consequences, Vol 61, No 1: 20-52.

Lee V, Handerson MC. (1996). Occupational stress and organizational commitment in nurse administrators. Journal of Nursing Administration. Vol 26, No 5. PP21-28.

Mowday R T, Porter L W, Steers RM. (1979). The Measurement of organizational commitment. Journal of Vocational Behavior( 14) : 224-247. 
Mowdey R T, Porter L W, Steers R M. (1982). Employee Organization Linkage, the Psychology of Commitment, Absenteeism and Turnaver, Newyork: Academic Press.

ZeinAbadi, H.R. (2009). Organizational citizenship behavior, job satisfaction and commitment to school: is there a significant difference between female and male teachers? Research and Scientific Journal of Female Studies, year 3, issue 1, PP. 4-27

O'reilly Ch, Chatman J. (1986). Organizational Commitment and Psychological Attachment: The Effects of Compliance, Identification, and Internalization on Prosocial Behavior. Journal of Applied Psychology, Vol 71, No 3: 492-499.

Emami, M. Nazari, K. (2011). Job attitudes. Tehran: Sokhanvaran Publication, 134 pages

SeyyedAmeri, M.H. Esmaeeli, M.R. (2010). Relationship between empowerment, organizational commitment and occupational commitment of employees working at Tehran Physical Education Headquarter. Sport Management, 2(7): 125-144

Sulu S, Ceylan A, Kaynak R. (2010). Work Alienation as a Mediator of the Relationship between Organizational Injustice and Organizational Commitment: Implications for Healthcare Professionals. International Journal of Business and Management Vol 5, No 8.

Kim YC, Rhee M. (2010). The contingent effect of social network on organizational commitment: A comparison of instrument and expressive ties in a multinational hightechnology company. Sociological perspectives. Vol 53, No 4, pp 479-502.

Bakker, A. B., Albrecht, S. L., \& Leiter, M. P. (2011). Key questions regarding work engagement.

Aminbidokhti, A. Salehpour, M. (2007). Relationship of job satisfaction to organizational commitment in employees of Education Organization. Danesh-e Raftar Quarterly. Publications of Shahed University, 14(26): 31-38

Inceoglu I, War P. (2012). Personality And Job Engagement. Jornal Of Personnel Psychology.

Hakanen J. Bakker A B, Schaufeli W B. (2006). Burnout and work engagement among teachers, The Journal of School Psychology, Vol 43, PP 495-513.

Schaufeli, W B, Bakker A. (2003). Utrecht Work Engagement Scale. Preliminary Manual, Vol 1,pp4-58 Available in: www.schaufeli.com.

Yakin M, Erdil O. (2012). Relationships Between Self-Efficacy and Work Engagement and the Effects on Job Satisfaction: A Survey on Certified Public. Procedia - Social and Behavioral Sciences, No 58, PP 370 - 378.

Kaveh, M. Ganji, F. (2014). Study of the relationship between the level of organizational commitment and work engagement among employees of Agricultural Jihad Organization and Education Organization employees in Shahrekord. The $2^{\text {nd }}$ National Conference on Psychology and Behavioral Science, Tehran, February $13^{\text {th }}$

Markos S. (2010). Employee engagement: the key to improving performance. International 


\section{Macrothink}

Journal Of Business And Management, Vol 5, pp 89-96.

Parsamoeeen, K. Nazem, F. (2010). Relationship of entrepreneurship and organizational commitment to job burnout. Organizational Industrial Psychological news quarterly, 1(3): 7-17.

Simons J C, Johanna H, Buitendach. (2013). Psychological capital, work engagement and organisational commitment amongst call centre employees in South Africa. SA Journal of Industrial Psychology, Vol 39, N 2.

Noori, A. Arizi, H. Zare, R. Babamiri, M. (2010). Relationship of the components of work engagement to the dimensions of organizational commitment. Journal of Industrial Organizational Psychological News, 1(5): 9-15.

Burke J R, Elkot G. (2010). Work engagement among managers and professionals in egipt. African Journal Of Economics And Management Studies, No 1, pp42-60.

Schaufeli W.B. Salanova M., González-Romá V, Bakker A.B. (2002). The measurement of engagement and burnout: A confirmatory factor analytic approach. Journal of Happiness Studies; (3): 71-92.

Field L.K, Buitendach J.H. (2011). Happiness, work engagement and organisational commitment of support staff at a tertiary education institution in South Africa. SA Journal of Industrial Psychology/SA Tydskrif vir Bedryfsielkunde, Vol37,No 1

Halbesleben JRB. (2008). A meta analysis of work engagement: relationships with burnout, demand, resources and consequences. In A Bakker And MP leiter (EDS). Work Engagement: Recent Development In Theory And Research, London.

\section{Copyright Disclaimer}

Copyright for this article is retained by the author(s), with first publication rights granted to the journal.

This is an open-access article distributed under the terms and conditions of the Creative Commons Attribution license (http://creativecommons.org/licenses/by/3.0/). 